\title{
An Infected Arterial Aneurysm and a Dog Bite: Think at Capnocytophaga canimorsus!
}

\author{
Mailys Ducours (iD) \\ Julie Leitao' \\ Mathilde Puges' \\ Sabine Pereyre $\mathbb{D}^{2,3}$ \\ Frédéric Gabriel (iD) 4 \\ Hervé Dutronc' \\ Raphaelle Chevallier' \\ Jean-Baptiste Pinaquy (D ${ }^{5}$ \\ Claire Carcaud ${ }^{6}$ \\ Xavier Berard ${ }^{7}$ \\ Charles Cazanave ${ }^{1,3}$ \\ 'CHU Bordeaux, Service des Maladies \\ Infectieuses et Tropicales, Hôpital Pellegrin, \\ Bordeaux, F-33000, France; ${ }^{2} \mathrm{CHU}$ \\ Bordeaux, Laboratoire de Bactériologie, \\ Hôpital Pellegrin, Bordeaux, F-33000, \\ France; ${ }^{3}$ University of Bordeaux, INRAE, \\ IHMC, USC EA 367I, Bordeaux, F-33000, \\ France; ${ }^{4}$ Centre Hospitalier Universitaire de \\ Bordeaux, Laboratoire de parasitologie- \\ mycologie, Hôpital Pellegrin, Bordeaux, \\ F-33000, France; ${ }^{5} \mathrm{CHU}$ Bordeaux, Service \\ de médecine nucléaire, Bordeaux, F-33000, \\ France; ${ }^{6} \mathrm{CHU}$ Bordeaux, Service \\ de médecine vasculaire, Bordeaux, F-33000, \\ France; ${ }^{7} \mathrm{CHU}$ Bordeaux, Service de chirur- \\ gie vasculaire, Bordeaux, F-33000, France
}

Correspondence: Charles Cazanave CHU Bordeaux, Service des Maladies Infectieuses et Tropicales, Groupe Hospitalier Pellegrin, Place Amélie RabaLéon, Bordeaux Cedex, 33076, France Email charles.cazanave@chu-bordeaux.fr

\begin{abstract}
We describe the fourth cases of arterial aneurysm consecutive to Capnocytophaga canimorsus infection in a 77-year-old man. The infection occurred after a dog bite. He presented fever. The thoracic-abdominal computed tomography angiography revealed aneurysms on the abdominal aorta, left common femoral artery, and left popliteal artery. The diagnosis was performed by a blood culture positive for Capnocytophaga canimorsus. The outcome was favorable with surgery and antibiotic therapy.
\end{abstract}

Keywords: Capnocytophaga canimorsus, vascular aneurysm, dog bite, cat bite, zoonosis

\section{Case Report}

A 77-year-old man presented with a 1-week history of asthenia, dyspnoea, and confusion after a dog bite on the left hand 10 days previously. He had a history of ischaemic stroke, dyslipidaemia, essential thrombocythaemia, and hypertension. He also reported histories of heavy alcohol consumption and 30 pack-year smoking. At admission, his temperature and heart and respiratory rates were $37.5^{\circ} \mathrm{C}, 100 / \mathrm{min}$, and $20 / \mathrm{min}$, respectively. Physical examination revealed oedema of the left leg. Blood tests showed haemoglobin $11 \mathrm{~g} / \mathrm{dL}$, total leucocyte count $37,400 / \mathrm{mm} 3$, with $33,660 / \mathrm{mm} 3$ neutrophils, platelet count 734,000/mm3, C-reactive protein $320 \mathrm{mg} / \mathrm{L}$, and serum creatinine $178 \mu \mathrm{mol} / \mathrm{L}$. Thoracic-abdominal computed tomography angiography revealed aneurysms on the abdominal aorta ( $38 \mathrm{~mm}$ diameter), left common femoral artery (43 $\mathrm{mm}$ diameter), and left popliteal artery (33 mm diameter) (Figure 1). Six days later, 18Ffluorodeoxyglucose positron emission tomography-CT confirmed three growing inflammatory aneurysms, on the left common femoral (diameter $64 \times 72 \mathrm{~mm}$, Standardised Uptake Value (SUV) 12) and left (diameter $43 \times 29 \mathrm{~mm}$, SUV 10) and right (diameter $35 \times 28 \mathrm{~mm}$, SUV 10) popliteal arteries (Figure 2); the abdominal aorta was normal. Cerebral magnetic resonance imaging and transthoracic and transoesophageal echocardiography were normal. While hospitalized, his left leg was very painful and increased in volume. Ultrasonography Doppler revealed thrombosis of the deep common and superficial femoral veins. The left common femoral and popliteal aneurysms were resected and replaced using the right saphenous vein. After 11 days, cultures of the femoral aneurysm were positive for Capnocytophaga canimorsus. Identification was performed using matrix-assisted laser desorption/ionization timeof-flight mass spectrometry (MALDI-TOF MS) on three different isolates. The MALDI-TOF MS score identification was 2, 29. The strain was susceptible in vitro to beta-lactams, aminoglycosides, fluoroquinolones, tetracycline, and trimethoprimsulfamethoxazole, and resistant to macrolides. A post-surgery blood culture was 


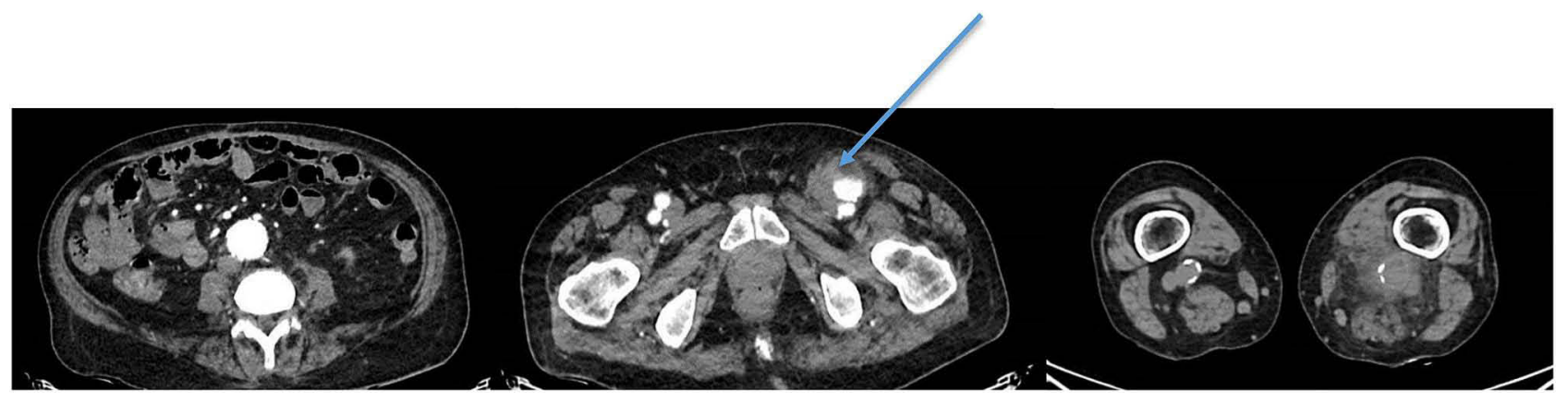

Figure I Axial section on computed tomography images. Arrow shows left common femoral artery aneurysm.

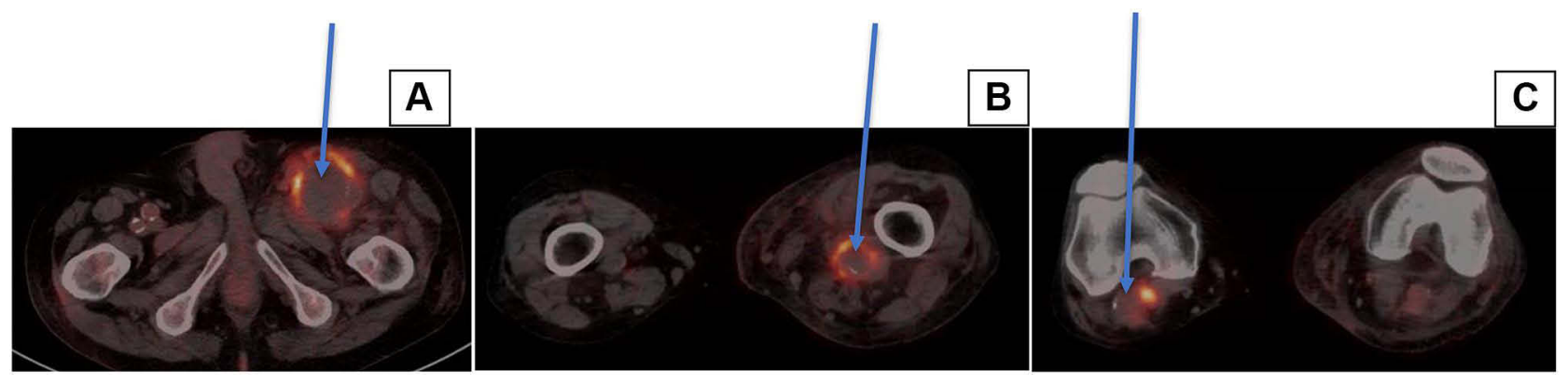

Figure 2 Axial section on PET-CT with FDG. Arrows show aneurysms. (A) Aneurysm on the left common femoral artery (SUV: I2), (B) Aneurysm on the left popliteal artery (SUV: I0), (C) Aneurysm on the right popliteal artery (SUV: 10).

Abbreviation: SUV, Standardized Uptake Value.

positive for Escherichia coli, probably due to a superinfection of aneurysms; identification was performed using MALDI-TOF MS; the bacteria has no acquired antibiotic resistance. The patient received piperacillin-tazobac$\operatorname{tam} 12 \mathrm{~g} /$ day, and then amoxicillin/clavulanic acid $6 \mathrm{~g} /$ day for 1 month, which allowed to the treat the two bacteria. No aetiology other than bacterial infection was found to explain the rapid expansion of this aneurysm. The symptoms and the incubation period was not in favor for a rabies. Other aetiology of infected aneurysms was eliminated by blood culture and serological test. Temporal artery biopsy was not in favor for a Horton disease. Serological tests performed for auto immune disease were negative. As his brother also has a history of arterial aneurysms, genetic research for a familial form of aneurysm is planned. The outcome was favourable.

\section{Discussion}

Belonging to the family Flavobacteriaceae, the genus Capnocytophaga consists of nine species: C. canimorsus, C. cynodegmi, C. gingivalis, C. granulosa, C. haemolytica, C. leadbetteri, C. ochracea C. sputigena and C. canis. ${ }^{1-3}$
C. canimorsus was first isolated from a man who developed septicaemia and meningitis following dog bites. It was first named dysgonic fermenter $2^{4}$ and given its current name in 1989 from the Greek kapnos ("smoke") for its dependence on carbon dioxide, cytophaga (Greek kytos "cell" and phagein "eat"), and the Latin canis ("dog") and morsus ("bite"). Three C. canimorsus serovars (A-C) cause most human infections. ${ }^{5}$ Hess et al first reported who determine the $\mathrm{C}$. canimorsus serovar by $\mathrm{PCR} ;^{6}$ this test is not performed routinely in our laboratory, and should not be performed for our patient. It is a commensal bacterium of the oral cavities of dogs and cats. A Japanese study found it in $74 \%$ and $57 \%$ of the oral cavities of dogs and cats, respectively. ${ }^{7}$ It is a slowgrowing, facultatively anaerobic, Gram-negative bacillus. Capnocytophaga spp. are fastidious bacteria; their optimal growth conditions include the use of specific culture media (agar chocolate or brain heart infusion), and an environment with $5-10 \% \mathrm{CO}_{2}$, temperature of $37^{\circ} \mathrm{C}$, and enriched atmosphere for at least 5 days. ${ }^{8}$ Transmission can occur through dogs' and cats' scratches, bites, or licking preexisting wounds; however, the sources of infection remain unknown in about $10 \%$ of described cases. Pet owners and 
people who have occupational associations with animals are at high risk of exposure to $C$. canimorsus. ${ }^{9}$ The incubation period before the onset of symptoms ranges from 1 to 7 days. Systemic infections occur most frequently in immunocompromised patients, such as asplenic, neutropenic, or alcoholic patients, patients with haematological malignancies or receiving chemotherapy, immunosuppressive therapy or long-term steroids, patients infected by the Human Immunodeficiency Virus, elderly patients, and patients with hemochromatosis or major betathalassemia. ${ }^{9-12}$ Reported clinical manifestations include bacteraemia, endocarditis, joint infections, peritonitis, meningitidis, vascular infection, disseminated intravascular coagulation, and thrombotic thrombocytopenic purpura. $^{8-20}$ Most patients have bacteraemia. ${ }^{16}$ C. canimorsus is often difficult to isolate and identify because of its specific nutrient requirements, so the frequency of $C$. canimorsus infection might be underestimated. ${ }^{15}$ Polymerase chain reaction (PCR) and sequencing of the $16 \mathrm{~S}$ ribosomal RNA (rRNA) is sometimes useful for identifying C. canimorsus. ${ }^{21}$ The diagnosis should be made in cases of endocarditis or joint infections with negative cultures and contact with an animal. $^{8,13}$ The slow growth of this organism may also result in difficulty performing antimicrobial susceptibility testing. C. canimorsus is usually susceptible to clindamycin, linezolid, tetracycline, imipenem, beta-lactamase inhibitor combination, and quinolones. It is always resistant to polymyxin, fusidic acid, fosfomycin, colimycine, and trimethoprim. It frequently produces a beta-lactamase, but susceptibility is restored by beta-lactamase inhibitors. ${ }^{14,22,23}$ Prevention of infection is mandatory after dog and cat bites by antibiotic prophylaxis with amoxicillin/clavulanic acid. Established infections should be treated with a penicillin-beta-lactamase inhibitor combination or a third-generation cephalosporin before obtaining antibiotic susceptibility. ${ }^{22,23}$ The duration of antibiotic therapy depends on the type of infection. In the case of septicaemia, the mortality is about $30 \% .^{16}$

The three reported cases of aortic aneurysm caused by $C$. canimorsus are summarised in Table $1 .{ }^{10,11,24}$ Two patients had cardiovascular risk factors and two also reported wounds contaminated with dog or cat saliva. All three needed emergency surgery because of impending rupture with worsening condition. The final diagnosis was made by culture in two patients [of the aortic wall $^{10}$ and blood ${ }^{11}$ ] and 16S rRNA gene sequencing definitively identified C. canimorsus. $^{10,11}$ In the third case, cultures were negative, but 16S rRNA sequencing from aortic tissue identified C. canimorsus. ${ }^{24}$ In our case,

Table I Patients Reported with Aortic Aneurysms Caused by C. canimorsus

\begin{tabular}{|c|c|c|c|c|c|c|c|c|}
\hline Publication & $\begin{array}{l}\text { Age, } \\
\text { Years }\end{array}$ & Gender & Risk Factors & Wound & $\begin{array}{l}\text { Clinical } \\
\text { Features }\end{array}$ & Diagnosis & Treatment & Outcome \\
\hline $\begin{array}{l}\text { Tierney } \\
\text { et al }{ }^{10}\end{array}$ & 65 & $M$ & $\begin{array}{l}\text { Cardiovascular } \\
\text { risk factors }\end{array}$ & $\begin{array}{l}\text { Dog } \\
\text { bite on } \\
\text { right } \\
\text { arm }\end{array}$ & $\begin{array}{l}\text { Fever, } \\
\text { lower } \\
\text { back pain }\end{array}$ & $\begin{array}{l}\text { Positive culture on } \\
\text { aortic wall, and } \\
\text { I6S rRNA gene } \\
\text { sequencing }\end{array}$ & $\begin{array}{l}\text { - Piperacillin-tazobactam, } \\
\text { then imipenem, then } \\
\text { amoxicillin-clavulanate, and } \\
\text { finally with ciprofloxacin for } \\
\text { at least } 6 \text { weeks } \\
\text {-Emergency surgery because } \\
\text { of the impeding rupture } \\
\text { worsening condition }\end{array}$ & Favorable \\
\hline $\begin{array}{l}\text { Rougemont } \\
\text { et al }{ }^{\prime \prime}\end{array}$ & 49 & $\mathrm{~F}$ & $\begin{array}{l}\text { HIV-infected } \\
\text { patient with an } \\
\text { aortic vascular } \\
\text { graft }\end{array}$ & No & $\begin{array}{l}\text { Fever, } \\
\text { lower } \\
\text { back pain }\end{array}$ & $\begin{array}{l}\text { Positive blood } \\
\text { cultures and } 16 \mathrm{~S} \\
\text { rRNA gene } \\
\text { sequencing }\end{array}$ & $\begin{array}{l}\text { - Piperacillin-tazobactam } \\
\text { - Emergency surgery } \\
\text { because of the impeding } \\
\text { rupture worsening condition }\end{array}$ & Death \\
\hline Chu et $\mathrm{al}^{24}$ & 69 & $\mathrm{H}$ & $\begin{array}{l}\text { Cardiovascular } \\
\text { risk factors }\end{array}$ & $\begin{array}{l}\text { Dog } \\
\text { bite on } \\
\text { hand }\end{array}$ & $\begin{array}{l}\text { Fever, } \\
\text { lower } \\
\text { back pain }\end{array}$ & $\begin{array}{l}\text { I6S rRNA gene } \\
\text { sequencing from } \\
\text { the aortic tissue } \\
\text { (negative } \\
\text { bacteriological } \\
\text { culture) }\end{array}$ & $\begin{array}{l}\text { - Intravenous meropenem } \\
\text { during } 4 \text { weeks, then } \\
\text { ciprofloxacin for } 6 \text { months } \\
\text { - Emergency surgery } \\
\text { because of the impeding } \\
\text { rupture worsening condition }\end{array}$ & Favorable \\
\hline
\end{tabular}

Abbreviations: F, female; M, male; $16 \mathrm{~S}$ rRNA, $16 \mathrm{~S}$ ribosomal ribonucleic acid. 
identification was performed using MALDI-TOF MS, with an identification score of $\geq 2.0$, which is considered an accurate species-level identification. This explains why we did not realise 16s rRNA gene sequencing. One patient was treated with piperacillin/tazobactam, then imipenem, then amoxicillin/clavulanate and, finally, with ciprofloxacin for at least 6 weeks, ${ }^{10}$ another with piperacillin/tazobactam, ${ }^{12}$ and the third with intravenous meropenem for 4 weeks, and then ciprofloxacin for 6 months. Ultimately, one patient died of haemorrhagic shock and ventilator-associated pneumonia.

In conclusion, we reported the fourth case of a rapidly growing arterial aneurysm caused by $C$. canimorsus infection after a dog bite. Since $C$. canimorsus is a fastidious bacterium, infection is often difficult to diagnose; contact with pets (dogs and cats) should be considered. Antibiotic therapy is mandatory, often associated with surgery, illustrating a multidisciplinary management.

\section{Consent Statements}

A written informed consent has been provided by the patient to have the case details and any accompanying images published. This work is consistent with the protection of personal health data and privacy under article 65-2, the amended Computer and Freedoms Act and the General Regulation of Personal Data Protection. Institutional approval was not required to publish the case details.

\section{Acknowledgments}

Dr ISSA Nahema and Dr CAMOU Fabrice, Réanimation médicale, Hôpital Saint André, CHU de Bordeaux.

\section{Disclosure}

The authors report no conflicts of interest in this work.

\section{References}

1. Renzi F, Dol M, Raymackers A, Manfredi P, Cornelis GR. Only a subset of Capnocytophaga canimorsus strains is dangerous for humans. Emerg Microbes Infect. 2016;5:1. doi:10.1038/emi.2016.43

2. Donner V, Buzzi M, Lazarevic V, et al. Septic shock caused by Capnocytophaga canis after a cat scratch. Eur J Clin Microbiol Infect Dis. 2020;39(10):1993-1995. doi:10.1007/s10096-020-03922-8

3. Taki M, Shimojima Y, Nogami A, et al. Sepsis caused by newly identified Capnocytophaga canis following cat bites: C. canis is the third candidate along with C. canimorsus and C. cynodegmi causing zoonotic infection. Intern Med. 2018;57(2):273-277. doi:10.2169/ internalmedicine.9196-17

4. Bobo RA, Newton EJ. A previously undescribed gram-negative bacillus causing septicemia and meningitis. Am J Clin Pathol. 1976;65 (4):564-569. doi:10.1093/ajcp/65.4.564
5. Hess E, Renzi F, Karhunen P, et al. Capnocytophaga canimorsus capsular serovar and disease severity, Helsinki Hospital District, Finland, 2000-2017. Emerg Infect Dis. 2018;24(12):2195-2201. doi:10.3201/eid2412.172060

6. Hess E, Renzi F, Koudad D, Dol M, Cornelis GR, Patel R. Identification of virulent Capnocytophaga canimorsus isolates by capsular typing. J Clin Microbiol. 2017;55(6):1902-1914. doi:10.1128/JCM.00249-17

7. Suzuki M, Kimura M, Imaoka K, Yamada A. Prevalence of Capnocytophaga canimorsus and Capnocytophaga cynodegmi in dogs and cats determined by using a newly established species-specific PCR. Vet Microbiol. 2010;144(1-2):172-176. doi:10.1016/j.vetmic.2010.01.001

8. Coutance G, Labombarda F, Pellissier A, et al. Capnocytophaga canimorsus endocarditis with root abscess in a patient with a bicuspid aortic valve. Heart Int. 2009;4(1):e5. doi:10.4081/hi.2009.e5

9. Gaastra W, Lipman LJA. Capnocytophaga canimorsus. Vet Microbiol. 2010;140(3-4):339-346. doi:10.1016/j.vetmic.2009.01.040

10. Tierney DM, Strauss LP, Sanchez JL. Capnocytophaga canimorsus mycotic abdominal aortic aneurysm: why the mailman is afraid of dogs. $J$ Clin Microbiol. 2006;44(2):649-651. doi:10.1128/JCM.44.2.649651.2006

11. Rougemont M, Ratib O, Wintsch J, Schrenzel J, Hirschel B. Capnocytophaga canimorsus prosthetic aortitis in an HIV-positive woman. J Clin Microbiol. 2013;51(8):2769-2771. doi:10.1128/ JCM.00321-13

12. Wilson JP, Kafetz K, Fink D. Lick of death: Capnocytophaga canimorsus is an important cause of sepsis in the elderly. BMJ Case Rep. 2016;2016:2016. doi:10.1136/bcr-2016-215450

13. Kelly BC, Constantinescu DS, Foster W. Capnocytophaga canimorsus periprosthetic joint infection in an immunocompetent patient: a case report. Geriatr Orthop Surg Rehabil. 2019;10:2151459318825199. doi:10.1177/2151459318825199

14. Jolivet-Gougeon A, Sixou J-L, Tamanai-Shacoori Z, BonnaureMallet M. Antimicrobial treatment of Capnocytophaga infections. Int $J$ Antimicrob Agents. 2007;29(4):367-373. doi:10.1016/j. ijantimicag.2006.10.005

15. Janda JM, Graves MH, Lindquist D, Probert WS. Diagnosing Capnocytophaga canimorsus infections. Emerg Infect Dis. 2006;12 (2):340-342. doi:10.3201/eid1202.050783

16. Lion C, Escande F, Burdin JC. Capnocytophaga canimorsus infections in human: review of the literature and cases report. Eur J Epidemiol. 1996;12(5):521-533. doi:10.1007/BF00144007

17. Mosher CB, Corp R. Mediastinal abscess with Capnocytophaga spp. in a competent host. $J$ Clin Microbiol. 1986;24(1):161-162. doi:10.1128/jcm.24.1.161-162.1986

18. Hartley JW, Martin ED, Gothard WP, Levine DF. Fulminant Capnocytophaga canimorsus (DF2) septicaemia and diffuse intravascular coagulation in hairy cell leukaemia with splenectomy. $J$ Infect. 1994;29(2):229-230. doi:10.1016/S0163-4453(94)90890-7

19. Tani N, Nakamura K, Sumida K, Suzuki M, Imaoka K, Shimono N. An immunocompetent case of Capnocytophaga canimorsus infection complicated by secondary thrombotic microangiopathy and disseminated intravascular coagulation. Intern Med. 2019;58(23):3479-3482. doi:10.2169/internalmedicine.3110-19

20. Ma A, Goetz MB. Capnocytophaga canimorsus sepsis with associated thrombotic thrombocytopenic purpura. Am J Med Sci. 2013;345(1):78-80. doi:10.1097/MAJ.0b013e318262db1a

21. Hansen M, Crum-Cianflone NF. Capnocytophaga canimorsus meningitis: diagnosis using polymerase chain reaction testing and systematic review of the literature. Infect Dis Ther. 2019;8(1):119-136. doi:10.1007/s40121-019-0233-6

22. Jolivet-Gougeon A, Buffet A, Dupuy C, et al. In vitro susceptibilities of Capnocytophaga isolates to beta-lactam antibiotics and beta-lactamase inhibitors. Antimicrob Agents Chemother. 2000;44 (11):3186-3188. doi:10.1128/AAC.44.11.3186-3188.2000 
23. Roscoe DL, Zemcov SJ, Thornber D, Wise R, Clarke AM. Antimicrobial susceptibilities and beta-lactamase characterization of Capnocytophaga species. Antimicrob Agents Chemother. 1992;36 (10):2197-2200. doi:10.1128/AAC.36.10.2197
24. Chu P, Howden BP, Jones S, Fell G, Roberts AK. Once bitten, twice shy: anunusual case report of a mycotic aortic aneurysm. ANZ J Surg. 2005;75(11):1024-1026. doi:10.1111/j.1445-2197.2005.03599.x

\section{Publish your work in this journal}

Infection and Drug Resistance is an international, peer-reviewed openaccess journal that focuses on the optimal treatment of infection (bacterial, fungal and viral) and the development and institution of preventive strategies to minimize the development and spread of resistance. The journal is specifically concerned with the epidemiology of

Submit your manuscript here: https://www.dovepress.com/infection-and-drug-resistance-journal antibiotic resistance and the mechanisms of resistance development and diffusion in both hospitals and the community. The manuscript management system is completely online and includes a very quick and fair peerreview system, which is all easy to use. Visit http://www.dovepress.com/ testimonials.php to read real quotes from published authors. 